\title{
PERBANDINGAN AIR PERASAN DAUN SAMBILOTO (ANDROGRAPHIS PANICULATA NEES) DAN SERAI (ANDROPOGON NARDUS) SEBAGAI DAYA TOLAK NYAMUK AEDES AEGYPTI
}

\author{
${ }^{1}$ Olviana, ${ }^{2}$ Miswan, dan ${ }^{3}$ Finta Amalinda \\ 1.Bagian Kesehatan Lingkungan, Fakultas Kesehatan, Universitas \\ Muhammadiyah Palu \\ 2Jurusan Biologi, Fakultas MIPA, Univeritas Tadulako Palu \\ ${ }^{3}$ Bagian Biostatistik, Fakultas Kesehatan, Universitas Muhammadiyah Palu
}

\begin{abstract}
ABSTRAK
Nyamuk Aedes aegypti merupakan serangga vektor penyakit demam berdarah dengue (DBD) yang berkembang biak pada pemukiman manusia. Penanggulangan dan pencegahannya lebih banyak mengandalkan pada pemutusan rantai penularan melalui pengendalian $A$.aegypti yang berperan sebagai vektor penular DBD. Penelitian ini bertujuan untuk Perbandingan Air Perasan Daun Sambiloto (Andrographis paniculata nees) Dan Serai (Andropogon nardus) Sebagai Daya Tolak Nyamuk Aedes aegypti. Jenis penelitian ini adalah Eksprimen untuk membandingkan efektitas air perasan tanaman sambiloto (Andrographis paniculata nees) dan serai (Andropogon nardus) sebagai penolak nyamuk Aedes aegypti. Penelitian ini berlokasi di Fakultas Kesehatan Masyarakat Universitas Muhammadiyah Palu dan telah dilaksanakan pada bulan Maret 2017. Dari hasil penelitian ini diperoleh hasil jumlah nyamuk yang hinggap pada tangan kanan yang telah diolesi air perasan sambiloto berjumlah 3 ekor nyamuk sedangkan pada tangan kiri yang telah diolesi air perasan serai berjumlah 23 ekor nyamuk. Dengan adanya penelitian ini diharapkan kepada masyarakat agar mampu membuat sendiri inteksida alami di rumah untuk mencegah terjadinya penyakit DBD yang di sebabkan oleh gigitan nyamuk Aedes aegypti.
\end{abstract}

Kata Kunci: Perasan daun Sambiloto, daun Serai, Aedes aegypti. 


\section{PENDAHULUAN}

Demam berdarah dengue (DBD) merupakan penyakit yang banyak ditemukan di sebagian besar wilayah tropis dan subtropis, terutama asia tenggara, Amerika tengah, Amerika dan Karibia. Host alami DBD adalah manusia, agentnya adalah virus dengue yang termasukkedalam famili Flaviridae dan genus Flavivirus, ditularkan ke manusia melalui gigitan nyamuk yang terinfeksi, khususnya nyamuk Aedes aegypti dan Ae. albopictus yang terdapat hampir di seluruh pelosok Indonesia. Masa inkubasi virus dengue dalam manusia (inkubasi intrinsik) berkisar antara 3 sampai 14 hari sebelum gejala muncul, gejala klinis rata-rata muncul pada hari keempat sampai hari ketujuh, sedangkan masa inkubasi ekstrinsik (di dalam tubuh nyamuk) berlangsung sekitar 8-10 hari (Budiman, 2014).

Demam berdarah dengue (DBD) merupakan penyakit yang banyak ditemukan di sebagian besar wilayah tropis dan subtropis,terutama di asia tenggara,Amerika Tengah,Amerika dan Karibia.Host alami DBD adalah manusia, Agentnya adalah virus dengue yang termaksud dalam famili Flaviridae dan genus Flavivirus,di tularkan ke manusia melalui gigitan nyamuk yang terinfeksi,khususnya nyamuk Aedes aegypti dan Ae.aLbopicitus yang terdapat hampir di seluruh pelosok Indonesia.Masa inkubasi virus dengue dalam manusia (Inkubasi intrinsik) berkisar antara 3 -14 hari sebelum gejala muncul,gejala klinis rata-rata muncul pada hari ke empat sampai hari ketujuh,sedangkan masa inkubasi ekstrinsik (di dalam tubuh nyamuk) berlangsung sekitar 8-10 hari chandra (2010) dalam Budiman (2014).

World Health Organization (WHO) mencatat Negara Indonesia sebagai negara dengan kasus Demam Berdarah tertinggi di Asia Tenggara. Dari jumlah keseluruhan kasus tersebut, sekitar 95\% terjadi pada anak di bawah 15 tahun (WHO 2014).

Hingga saat ini pengendalian nyamuk belum bisa di tanggulangi dengan optimal. Disamping penyebarannya yang sangat luas dari wilayah perkotaan hingga ke pelosok pedesaan, nyamuk tersebut juga sangat mudah berkembang biak terutama dilingkungan sekitar tempat manusia beraktivitas. Tempat perindukan nyamuk tersebut sangat bervariasi, tetapi umumnya lebih menyukai berbagai macam tempat penampungan air jernih yang banyak terdapat disekitar pemukiman penduduk, seperti bak mandi, tempayan dan barang-barang bekas yang menampung sisa-sisa air hujan (Aprianto Jacob 2014).

Demam berdarah dengue mulai ditemukan di Sulawesi Tengah 
sejak tahun 1992 dengan kasus suspek DBD sebanyak 8 orang, pada tahun 1993 meningkat menjadi 17 orang dan pada tahun 1994 meningkat lagi menjadi 44. Mulai tahun 1996, keadaan di Sulawesi Tengah cukup memprihatinkan karena dari 50 kasus suspek ditemukan 16 penderita yang positif DBD dan terjadi kematian pada 4 penderita. Sampai saat ini telah ditemukan 2.092 kasus dengan 29 kasus meninggal dan IR 79,4/100.000 penduduk CFR 1,4\% (Muliansyah, 2016).

Andrographis paniculata nees. atau yang biasa dikenal dengan nama daerah sambiloto merupakan tanaman obat yang secara empiris digunakan sebagai antimalaria. Penelitian terdahulu menunjukkan bahwa ekstrak tanaman ini mempunyai aktivitas antimalaria dengan cara menghambat pertumbuhan Plasmodium falciparum (Kusumawardhani Dwi,dkk 2005).

Insektisida alternatif yang aman bagi lingkungan berasal dari tumbuhan. Menurut pendapat Kardinan, Sebenarnya untuk menghindari gigitan nyamuk dan membasmi nyamuk dapat digunakan bahan dari alam tanpa harus menggunakan insektisida yang dapat mempengaruhi kesehatan. Bahan yang berasal dari alam itu menghasilkan bahan anti nyamuk yaitu daun, akar, batang, biji, dan bunganya dapat dimanfaatkan dan diolah sebagai bahan pengusir nyamuk (Manurung Rofirma, dkk 2015).

Diantara tanaman penghasil bahan anti nyamuk tersebut adalah tanaman Serai Wangi. Menurut Flona, Serai Wangi (Cymbopogon nardus) menghasilkan minyak pati atau minyak atsiri yang dikenal sebagai Citronella Oil. Minyak citronella mengandung dua senyawa kimia penting yaitu Sitronelal dan Geraniol, yang berfungsi sebagai pengusir nyamuk, tetapi Flona tidak menyebutkan konsentrasi berapa serai wangi efektif untuk menolak gigi tannyamuk (Manurung Rofirma, dkk 2015).

Provinsi sulawesi Tengah mempunyai potensi yang besar terhadap terjadinya Kejadian Luar Biasa (KLB),mengingat daerah ini di kelelilingi oleh daerah daerah yang endemis dan kepadatan vektor yang tinggi. Jumlah kasus DBD di Provinsi Sulawesi Tengah pada tahun 2015 masih mengalami peningkatan dari tahun 2014 yang sempat mengalami penurunan jumlah kasus DBD, pada tahun 2015 yakni sebesar 1.579 kasus dengan 11 di antaranya penedrita meninggal dunia, sedangkan tahun 2014 yakni 1.308 kasus DBD.Untuk Kota Palu pada tahun 2015 jumlah kasus sebanyak 650 kasus meninggal dunia, kabupaten Donggala 18 kasus, Kabupaten Parigi Mautong 16 kasus 
DBD dengan 2 di antaranya meninggal dunia, Kabupaten Poso memiliki jumlah kasus sebesar 179 kasus 2 di antaranya meninggal dunia, Kabupaten Tojo Una-Una dengan 26 jumlah kasus, Kabupaten Toli-Toli memiliki 220 kasus dengan 2 diantaranya meninggal dunia, Kabupaten Morowali terdapat 81 kasus, Kabupaten Morowali Utara jumlah kasus 26, Kabupaten Buol 231 kasus dengan 1 orang di antaranya meninggal dunia, Kabupaten Banggai Laut tidak terdapat kasus DBD (Dinkes Sulteng, 2015).

Berdasarakan uraian diatas maka peneliti tertarik untuk melakukan penelitian tentang "Perbandingan Air Perasan Daun Sambiloto (Andrograpis paniculata Ness) dan Serai (Andropogon nardus) Sebagai Daya Tolak Nyamuk Aedes aegypti'.

\section{METODE}

penelitian ini merupakan penelitian Eksprimen untuk membandingkan efektifitas air perasan tanaman sambiloto (Andrographis paniculata nees) dan serai (Andropogon nardus) sebagai penolak nyamuk Aedes aegypti.

\section{HASIL}

Penulis telah melakukan perbandingan evektivitas perasan sambiloto sebagai pengusir nyamuk Aedesaegypti dengan perlakuan 5 $\mathrm{ml}, 10 \mathrm{ml}$, dan $15 \mathrm{ml}$. Hasil perbandingan dapat dilihat pada.

\section{Tabel 1 Perbandingan efektifitas Perasan Sambilotodan Serai sebagai pengusir Nyamuk PadaPerlakuan $5 \mathrm{ml}, 10 \mathrm{ml}$, dan $15 \mathrm{ml}$}

\begin{tabular}{|c|c|c|c|c|c|c|c|c|}
\hline \multirow{3}{*}{ No } & \multirow{3}{*}{$\begin{array}{l}\text { Perlakuan } \\
\text { (ml) }\end{array}$} & \multirow{3}{*}{$\begin{array}{c}\text { Jumlah } \\
\text { Nyamuk yang } \\
\text { Hinggap pada } \\
\text { Kontrol }\end{array}$} & \multicolumn{6}{|c|}{$\begin{array}{c}\text { Jumlah Nyamuk } \\
\text { Yang Hinggap }\end{array}$} \\
\hline & & & \multicolumn{3}{|c|}{$\begin{array}{c}\text { Sambilot } \\
0\end{array}$} & \multicolumn{3}{|c|}{ Serei } \\
\hline & & & 1 & II & III & I & II & III \\
\hline 1 & 5 & 2 & 1 & 1 & 1 & 3 & 5 & 1 \\
\hline 2 & 10 & 6 & 0 & 0 & 0 & 6 & 2 & 3 \\
\hline 3 & 15 & 20 & 0 & 0 & 0 & 0 & 1 & 2 \\
\hline Jumlah & & 18 & 1 & 1 & 1 & 9 & 8 & 6 \\
\hline
\end{tabular}

Sumber: Data Primer, 2017

Berdasarkan tabel 1, hasil eksperimen yang pertama pada perlakuan $5 \mathrm{ml}$ dengan pengulangan tiga kali di dapatkan hasil sebagai berikut: pada perlakuan kontrol 2 ekor nyamuk yang hinggap, untuk 
perasan sambiloto pada perlakuan pertama terdapat 1 ekor nyamuk yang hinggap, sedangkan pada perasan serai perlakuan pertama berjumlah 3 ekornyamuk yang hinggap. Hasil eksperimen pengulangan yang kedua di dapatkan pada perlakuan control terdapat 6 ekor nyamuk yang hinggap, perasan sambiloto tidak ada nyamuk yang hinggap, sedangkan pada perasan serai 6 ekor nyamuk yang hinggap. Pada hasil eksperimen pengulangan yang ketiga di dapatkan pada perlakuan kontrol 10 ekor nyamuk yang hinggap, perasan sambiloto tidak ada nyamuk yang hinggap, dan perasan serai tidak ada nyamuk yang hinggap.

Hasil eksperimen yang kedua pada perlakuan $10 \mathrm{ml}$ dengan pengulangan tiga kali di dapatkan hasil sebagai berikut: pada perasan sambiloto pada perlakuan yang pertama 1 ekor nyamuk yang hinggap, pada perasan serai 5 ekor nyamuk yang hinggap, dan pada perasan sambiloto pengulangan kedua tidak ada nyamuk yang hinggap, pada perasan serai 2 ekor nyamuk yang hinggap, pada hasil eksperimen pengulangan yang ketiga di perasan sambiloto tidak ada nyamuk yang hinggap, dan perasan serai 1 ekor nyamuk yang hinggap

Hasil eksperimen yang ketiga pada perlakuan $15 \mathrm{ml}$ dengan pengulangan tiga kali diperoleh hasil sebagai berikut: pada perasan sambiloto pada perlakuan yang pertama 1 ekor nyamuk yang hinggap, pada perasan serai 1 ekor nyamuk yang hinggap, dan pada perasan sambiloto pengulangan kedua tidak ada nyamuk yang hinggap, pada perasan serai 3 ekor nyamuk yang hinggap, pada hasil eksperimen pengulangan yang ketiga di perasan sambiloto tidak ada nyamuk yang hinggap, dan perasan serai 2 ekor nyamuk yang hinggap.

\section{PEMBAHASAN}

1. Serei Wangi

Serei merupakan tanaman bermarga Androgopon, nardus dengan nama spesies Androgoponnardus L, serai merupakan rumput-rumputan tegak, menahun dan mempunyai perakaran yang sangat dalam dan kuat. Batangnya membentuk rumpun, pendek, massif dan bulat. Penampang lintang batang berwarna merah. Daun serei merupakan daun tunggal, lengkap dan pelepah daunya silindris, gundul, seringkali bagian permukaan dalam berwarn amerah, ujung berlidah (Ligula), 
helaian, lebih dari separuh menggantung, remesan berbau aromatik. Susunan bunganya malai atau bulir majemuk, bertangkai atau duduk, berdaun pelindung nyata, biasanya berwarna sama umumnya putih (Suharmiati, 2007).

Serai wangi juga dapat dimanfaatkan sebagai pengusir nyamuk karena tanaman ini mengandung zat geraniol, metilheptenon, terpen, terpenalkohol, dan asam-asam organic yaitu sitonelal. Zat sironelal ini memiliki racun kontak sehingga nyamuk dapat kekurangan air (Agroloka 2015).

Kandungan dari serei yang utama adalah minyak astsiri dengan komponen sitronelal 32$45 \%$, geraniol asetat $2-4 \%$, sitral, kavikol, eugenol, elemol, kadinol, kadinen, vanilin, limonen, kamfen. Minyak serai mengandung 3 komponen utama, yaitu sitronelal, sitronelol, dan geraniol (Suharmiati, 2007). Jumlah total nyamuk yang hinggap pada tangan yang di olesi serei sebanyak 23 ekor nyamuk.

\section{Sambiloto}

Sambiloto, Salah satu herbal dari jenis tanaman perdu yang sudah dikenal cukup lama memiliki multi khasiat. Tanaman dari famili Acanthaceae tersebut tumbuh secara alami di dataran rendah dengan ketinggian \pm 1600 $\mathrm{m}$ dpl, yakni meliputi habitat seperti sawah, kebun, atau hutan. Andrographolide merupakan komponen senyawa utama dari sambiloto yang memiliki banyak khasiat seperti anti inflamasi, antioksidan.

Antidiabetes, serta anti aterosklerosis. Andrographolide senyawa yang menyebabkan sambiloto terasa pahit pada semua bagiannya, mulai dari daun, batang, bunga hingga akar.

Daun sambiloto mengandung saponin, falvonoid, alkaloid dan tanin. Kandungan kimia lain yang terdapat pada daun dan batang adalah laktone, panikulin, kalmegin dan hablur kuning yang memiliki rasa pahit. Secara tradisional sambiloto telah dipergunakan untuk pengobatan akibat gigitan ular atau serangga, demam, disentri, rematik, tuberculosis, infeksi pencernaan, dan lain-lain. Sambiloto juga dimanfaatkan untuk antimikroba/anti bakteri, anti sesak napas dan untuk memperbaiki fungsi hati. Mengingat kandungan dan fungsi tanaman tersebut, saat ini sambiloto banyak diteliti untuk dikembangkan sebagai bahan baku obat modern, diantaranya pemanfaatan sambiloto sebagai 
obat HIV dan anti kanker (Assajjad 2008).

Andrographis paniculata mengandungditerpene, laktone, dan flavanoid. Flavanoid terutama ditemukan diakar tanaman, tetapi jugaditemukan pada bagian daun. Bagian batang dan daun mengandung alkana, ketone dan aldehid. Meskipun di awal diduga bahwa senyawa yangmenimbulkan rasa pahit adalah senyawa andrographolide, lebih lanjut diketahui bahwa daun sambiloto mengandung dua senyawa yang menimbulkan rasa pahit yakni andrographolide dan senyawa yang disebut dengan kalmeghin. Empat senyawa lakton yang ditemukan dalam daun sambiloto (Ratnani, 2012).

Dari hasil penelitian terdahulu perbandingan air perasan tapak dara dan serai yang paling efektif adalah tanaman serai hal ini disebabkan karena adanya zat sironelal, sironelal ini memiliki racun kontak sehingga nyamuk dapat kekurangan air.

Dari hasil penelitian yang telah di lakukan jumlah nyamuk yang hinggap pada tangan kanan yang telah di olesi perasan sambiloto dari pengulangan I, II, dan III berjumlah 3 ekor nyamuk, sedangkan pada tangan kiri yang telah di oleskan perasan serai dari pengulangan I, II, dan III berjumlah 23 ekor nyamuk. Maka dapat di simpulkan bahwa daya pengusir terhadap nyamuk air perasan sambiloto lebih efektif bila di bandingkan dengan air perasan serei.

\section{KESIMPULAN}

Berdasarkan hasil penelitian dan pembahasan maka peneliti menarik kesimpulan sebagai berikut.

1. Daya usir terhadap nyamuk

Perasan daun Sambiloto lebih efektifbila di bandingkan dengan perasan serai hal ini dapat dilihat dari sedikitnya nyamuk yang hinggap di tangan yang diolesi sambiloto disbanding tangan yang diolesiserei.

2. Dengan adanya penelitian ini, diharapkan kepada masyarakat agar mampu membuat sendiri inteksida alami di rumah untuk mencegah terjadinya penyakit DBD yang di sebabkan oleh gigitan nyamuk aedes aegypti.

\section{REKOMENDASI}

1. Bagi Instansi

Sebagai bahan masukan dan pertimbangan dalam perencanaan menanggulangi penyakit demam berdarah dengue (DBD) khususnya bagi pihak terkait tentang pengen dalian vector penyebab demam berdarah dengue (DBD). 
2. Bagi Institusi

Sebagai bahan kepada instansi Perguruan Tinggi Universitas Muhammadiyah Palu, khususnya Fakultas Kesehatan Masyarakat tentang pemanfaatan perasan sambiloto dan serai dalam mengusir nyamuk Aedes aegypti.

\section{DAFTAR PUSTAKA}

Assajjad 2008, Manfaat Daun Sambiloto di unduh dari http://assajad.wordspress.co $\mathrm{m} / 2008 /$ manfaat-daun-

sambiloto (6 0ktober 2016)

Apprianto Jacob, Victor D. Pijoh, G.J.P Wahongan 2014, Ketahanan Hidup Dan Pertumbuhan Nyamuk Aedes spp Pada Berbagai Jenis Air Perindukan . Jurnal eBiomedik (Ebm), Volume 2, Nomor 3, November 2014

Agroloka 2015, ciri-ciri tanaman daun serei wangi (Cymbopogon nardus) www.agroloka.com.

Magelang

Budiman,

Rahmawati.2014.

Perbandingan Efektivitas Ekstrak Zodia (Evodia sauveolens) dan Serai (Cymbopogan citratus) Sebagai Repellent (Penolak) Nyamuk.Bagian Kesehatan
Lingkungan. Universitas Muhammadiyah Palu

Dinas Kesahatan Provinsi Sulawesi Tengah, 2015. Profil Dinas Kesehatan Provinsi Sulawesi Tengah. Palu.World Health Organization Data penyakit DBD 2014

Kusumawardhani

D, Widyawaruyanti

A, Kusumawati I, 2005. Efek Antimalaria

Sambiloto Ekstrak (Parameter Terstandar Aandrografolida) Mencit Kadar Plasmodium Pada Terinfeksi Majalah Farmasi Airlangga, Vol.5 No. 1, April 2005.

Muliansyah1, Tri Baskoro 2016. Analisis Pola Sebaran Demam Berdarah Dengue Terhadap Penggunaan Lahan Dengan Pendekatan Spasial Di Kabupaten Banggai Provinsi Sulawesi Tengah Tahun 2011-2013. Journal of Information Systems for Public Health, Vol. 1, No. 1, April 2016.

Manurung Rofirma, Indra Chahaya, Surya Dharma 2015. Pengaruh Daya Tolak Perasan Serai Wangi 
(Cymbopogon nardus) Terhadap Gigitan Nyamuk Aedes aegypti. Dapartemen Kesehatan Lingkungan Fakultas Kesehatan Masyarakat,Universitas Sumatera Utara, Medan, 2015, Indonesia.

Ratnani, (2012). Ensiklopedia Tanaman Obat Tradisional. Cetakan pertama Media Presindo. Yogyakarta.

Suharmiati, 2007. Tanaman obat ramuan tradisional untuk mengatasi demam berdarah DENGUE. Agro media pustaka Jakarta Selatan.
World Health Organization , 2014 Dengue and severe centre/factsheets/fs117/en 